\title{
骨付き膝蓋腱を用いた膝前十字勒带再々建術の検討
}

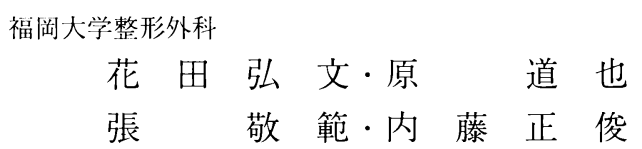

\section{Revision Surgery for Reconstructed Ruptured Anterior Cruciate Ligament Using Bone-Patellar Tendon-Bone Graft}

\author{
Hirofumi Hanada, Michiya Hara, Keihan Cho, \\ and Masatoshi Naito \\ Department of Orthopaedic Surgery, \\ School of Medicine, Fukuoka University, Fukuoka, Japan
}

Recent findings in both basic studies and clinical studies have led to the improvement of the outcome of anterior cruciate ligament (ACL) reconstruction. However, graft failure occasionally occurs, resulting in the need for revision ACL reconstruction. Some technical difficulties exist which are specific to revision surgery. In this paper, we describe our methods for evaluating patients with failed ACL reconstruction in order to investigate the mechanism of failure to improve future preoperative planning. $6 \mathrm{pa}-$ tients consisting of 5 males and 1 female, with an average age of 24 years (ranging from 20 to 31 years) were studied. The average time from primary to revision ACL surgery was 48 months (ranging from 18 to 72 months). All patients who underwent revision ACL surgery were studied postoperatively (all with harvested contralateral patellar tendon grafts). We also reviewed stability (Lachman test, Pivot shift test) and recurvatum, and performed radiographic examination.

Lachman test was -(nagative) in 5 cases and \pm in 1 case after the patients resumed their regular sports activity. After revision ACL reconstruction, the findings were (negateve) in 3 cases and \pm in 3 cases. Pivot shift test was -(negative) in 6 cases after the patients resumed their regular sports activity. After revision ACL reconstruction, the findings were -(negative) in 4 cases and \pm in 2 cases.

The recurvatum was $15^{\circ}$ in 1 case and $5^{\circ}$ in 1 case.

The side to side difference in the anterior laxity was $2.2 \mathrm{~mm}$ measured with Telos SE after the patients resumed their regular sports activity. After revision ACL reconstruction, it was $2.5 \mathrm{~mm}$.

From the magnetic resonance imaging (MRI) findings, low signal intensity was observed in 2 cases, intermediate intensity in 3 cases and high signal intensity in 1 case after the patients resumed their regular sports activity. After revision ACL reconstruction, low signal intensity was observed in 1 case while intermediate intensity was observed in 5 cases.

The failure cases were due to sports. In addition, 1 case had inadequate rehabilitation.

The Lysholm Knee Scores were 94.2 after the patients resumed their regular sports activity, 90.5 after revision ACL reconstruction.

The main causes of failed ACL reconstruction were sports related re-injuries. In order to reduce the occurrence of such sports related re-injuries, proper attention should 
be paid to such factors as: notch impingement, general joint laxity and inadequate rehabilitation.

Key words : anterior cruciate ligament (膝前十字勒帯), reconstruction (再建術), revision surgery（再々建術）

\section{はじめに}

近年, 膝前十字勒帯 (以下 ACL) 再建術は基礎的

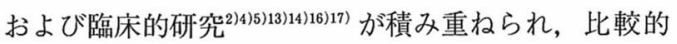
安定した術後成績が得られるようになった。しかしそ の一方では, 手術症例の増加に伴って術後経過の思わ しくない症例や, スポーツ復帰後に再建勒帯の再断裂 が生じた症例を経験することがある。近年，ACL再々 建術に関する報告(6)7121219-21) も散見されるが, 他施設で 初回手術を行ったものに対するACL 再々建術につい て報告したものが多く, 再手術に至った要因を詳細に 評価したものは少ない. 本研究の目的は, 当院抒よび 関連施設にて骨付き滕蓋腱（以下 BTB）を用いた ACL 再建術を施行し, 再断裂を生じ再々建術に至っ た症例に対し再断裂の危険因子を検討し, 再断裂の発 生を予防することである。

\section{対象および方法}

1991 年 10 月から 1999 年 3 月まで当院および関連 施設にて BTBによる ACL 再建術を施行した 514 例 中, BTB の再断裂を生じ, 再々建術を施行した男性 5 例, 女性 1 例の計 6 例である. 年齢は 20 31 歳, 平均 24 歳であった。初回再建術から再々建術までの 期間は 18〜 72 ケ月, 平均 48 ケ月であった. 再々建術 後の経過観察期間は $8 \sim 52$ ケ月, 平均 28 ケ月であっ た。再断裂を生じた原因は全例スポーツによる再受傷 で, 受傷肢位は全例膝外反, 下腿内旋であった。再々 建材料には全例 BTB を健側から採取した。これらの 症例に対して関節動摇性, 反張滕の有無, Lysholm score, 画像所見について検討を行った.

\section{結果}

徒手不安定検査：Lachman test はスポーツ復帰 時陰性が 5 例, 偽陽性が 1 例であったが, 再々建術後 は陰性が 3 例で, やや緩めの偽陽性が 3 例残った（図 1). Pivot shift test ではスポーツ復帰時は全例陰性
であったが，再々建術後は陰性が 4 例になり，偽陽性 が 2 例残った（図 2).

反張膝: 再断裂の要因と思われる反張膝を有したも のは 2 例であった（図 3).1 例は初回再建術前が伸展 $15^{\circ}$, もう 1 例は初回再建術前が伸展 $5^{\circ}$ であったが, 2 例とも再々建術後は反張膘が消失していた.

Lysholm score : スポーツ復帰時が平均 94.2 点, 再々建術後が平均 90.5 点で, 再々建術後は初回再建 術後と比較するとやや成績は劣る傾向にあった．

\begin{tabular}{r|c|c}
\hline \hline & スポーツ復帰時 & 再々建術後1 年 \\
\hline Lachman test $(+)$ & なし & なし \\
\hline$( \pm)$ & 1 例 & 3 例 \\
\hline$(-)$ & 5 例 & 3 例 \\
\hline
\end{tabular}

図 1 Lachman test 再々建術後にやや緩めの偽陽性が 3 例残った.

\begin{tabular}{r|c|c}
\hline \hline & スポーツ復帰時 & 再々建術後1 年 \\
\hline Pivot shift test $(+)$ & なし & なし \\
\hline$( \pm)$ & なし & 2 例 \\
\hline$(-)$ & 6 例 & 4 例 \\
\hline
\end{tabular}

図 2 Pivot shift test 再々建術後は偽陽性が 2 例残った.

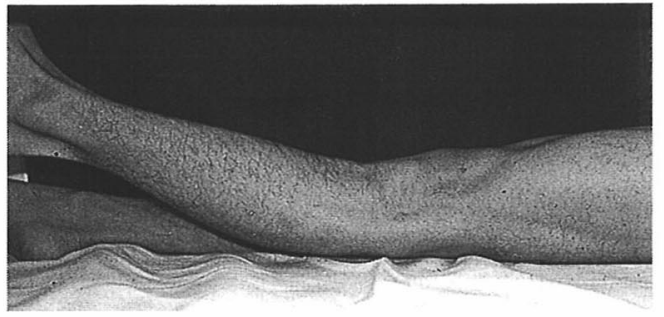

図 3 再断裂の要因と思われる反張滕 $\left(10^{\circ}\right)$ を呈し ていた. 
Lachman ストレス X 線 : 膝関節 $30^{\circ}$ 屈曲位で $15 \mathrm{lb}$ の負荷をかけ脛骨前方移動距離を計測した。脛 骨前方移動距離の対健側差は, スポーツ復帰時は平均 $2.2 \mathrm{~mm}$, 再々建術後は平均 $2.5 \mathrm{~mm}$ で初回再建術後 と比較するとやや脛骨の前方移動が認められた. また 当科における他の初回再建術の成績よりもやや劣る結 果であった。

MRI : スポーツ復帰時はプロトン密度強調画像に おいて, 再建勒帯が low intensityを呈したのは 2 例, intermediate が 3 例, 再建勒带の notch impingementを呈したと思われる high intensityの 1 例であったが, 再々建術後は high intensity の症例 は消失し, intermediateが 5 例に増加し, low intensity を呈したものが 1 例になった（図 4).

\section{症例 供 覧}

\section{〔症例 1〕 24 歳男性, 体操選手}

1993 年 7 月に右膝再建術を施行した。大腿四頭筋 筋力の患健比が $80 \%$ 以下にもかかわらず, 我々の許 可も無く術後 3 ケ月よりスポーツ復州し, 体操中に膝 外反, 下腿内旋で受傷し再断裂した。1995 年 2 月に 再々建術を施行した. 再々建術後の Lachman test, pivot shift test は偽陽性であった. 再々建術後 4 年 4 ケ月の現在, 競技レベルのスポーツは行っていない が, 日常生活に支障なく, 満足度も良好である（図5).

〔症例 2〕21 歳女性, ハンドボール選手

反張膝（伸展 $5^{\circ}$ ) を有する。 1994 年 9 月に右滕再 建術を施行した. 1996 年 8 月, ハンドボール中に膝 外反，下腿内旋で受傷し再断裂した。1997 年 5 月に 再々建術を施行した. MRI はスポーツ復帰時はやや 彎曲した intermediateから low intensityであっ

\begin{tabular}{lcc}
\hline \hline & スポーツ復帰時 & 再々建術後 1 年 \\
\hline low & 2 例 & 1 例 \\
\hline intermediate & 3 例 & 5 例 \\
\hline high & 1 例 & なし \\
\hline
\end{tabular}

図 4 MRI 評価 impingementを呈したと思われる high の 1 例が再々建後は消失し intermediate が 5 例に増加した.
たが, 再々建術後 1 年時は intermediate に変化して いた. 再々建術後 2 年の現在, 反張膝は消失した. 競 技レベルのスポーツは行っていないが, 日常生活に支 障なく, 満足度も良好である(図 6).

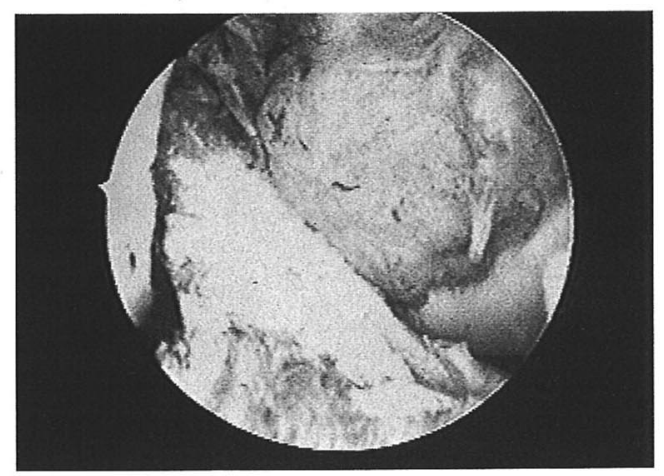

a 再建術時

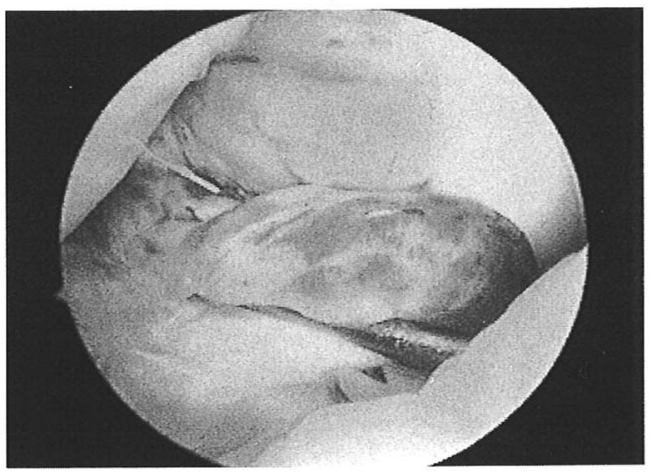

b 再建勒帯断裂

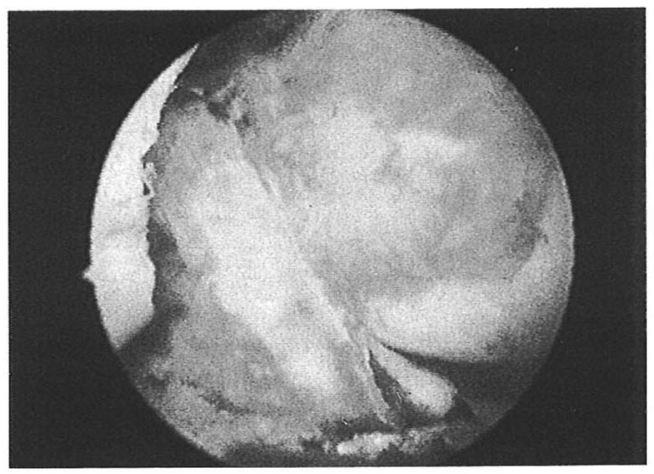

c 再々建術時

図 5 症例 $1: 24$ 歳男性 


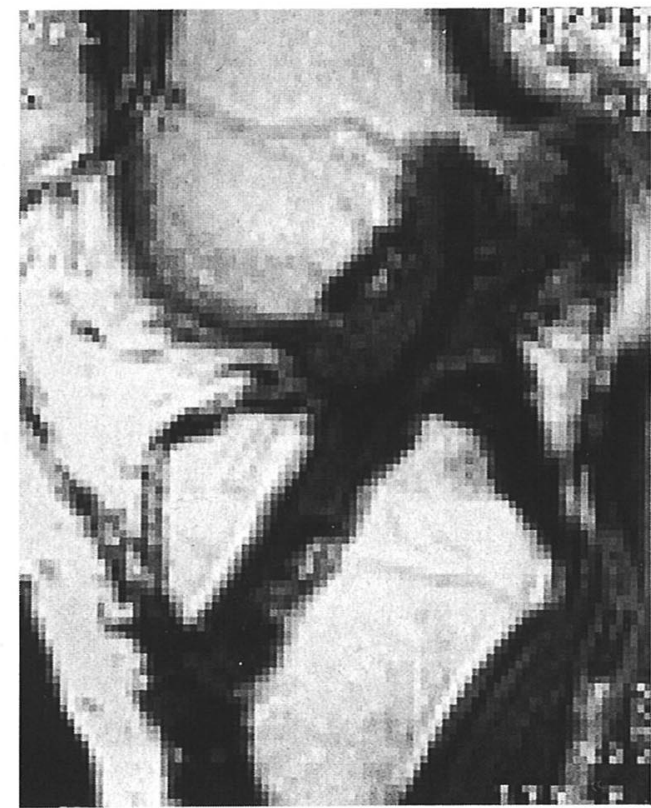

a スポーツ復帰時

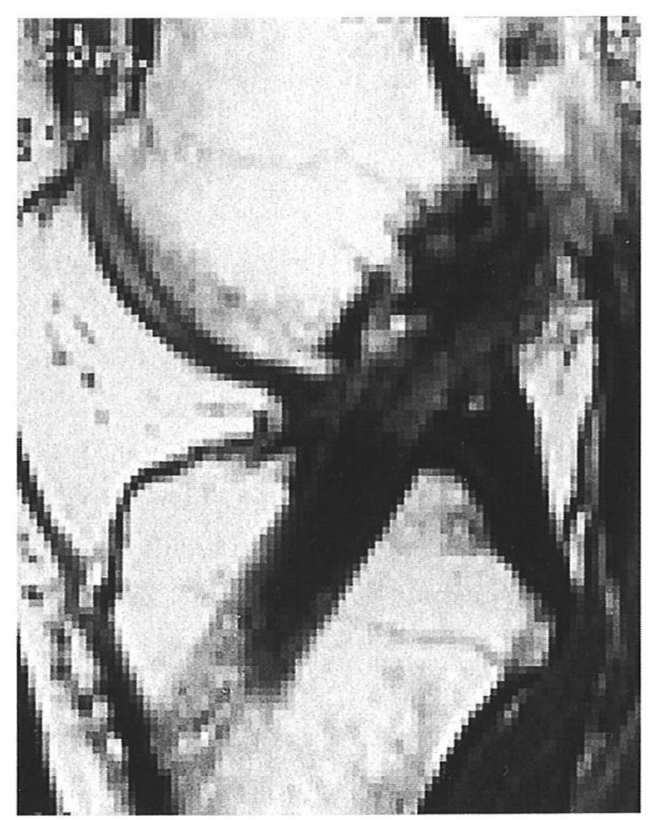

b 再々建術後 1 年

図 6 症例 : 21 藏症例

a スポーツ復帰時はやや彎曲した intermediateから low intensityであった.

b 再々建術後 1 年時は intermediate に変化していた.

\section{考察}

膝前十字勒帯（以下 ACL）再建術は基礎的および 臨床的研究 (2)151313141461)17) が積み重ねられ, 安定した術後 成績が得られるようになった，再建材料として当初は 腸脛勒带が多用されていたが，その後 BTB が gold standard $^{13)}$ となったが，近年はハムストリングスを 用いる傾向も徐々に増えつつある。一方，人工勒带 (Leeds-Keio 人工勒帯) などを用いたものもある. しかし，いかなる材料を用いても再建勒带の再断裂は 避けることのできない合併症の一つであり，その報告 例も散見されるようになってきだ(7)1219-21). 我々は手 術症例と文献を参照し以下の項目について考察した. （1）再断裂の原因，（2）再々建材料の選択，（3）再断 裂の予防.

（1）ACL 再断裂の原因

Johnson", Uribe ${ }^{19)} ら は$ 手術手技の問題によるも の, 再受傷によるもの, 再建材料の再生不良または固 定力不足によるものを挙げて扔り，骨孔作製位置の不 良などの手術手技に問題がある場合が最も多かったと
述べている. 今回の検討症例では, 脛骨の骨孔が Blumensaat's line の前方に作製された症例は 1 例 も見られず，再建材料（BTB）の再生不良または固 定力不足などに問題があったと思われるものもなく， 全例スポーッでのストップ, ターン時の膝外反, 下腿 内旋の一定の受傷肢位の繰り返しょるものであった (図 7). また我々は今回の検討症例から, スポーツ外 傷に伴う ACL 再断裂を助長する因子として, 大腿骨 顆間窩での再建勒带の impingement, 全身関節弛緩 (反張膝), 不十分な術後療法などを考えた.

(2) 再々建材料の選択

初回再建時にBTBが採取されている場合, Karns ${ }^{8)}$ らは再建術後 4 年で再断裂した症例に, 再度同側より 採取した再々建術を報告している. 我々も以前に再建 術後 10 年以上経過した 2 症例に同様の方法で再々建 術を施行したが, BTBは十分に再生されており特に 問題はなかった5).だが, 腱付着部での組織再生には 問題があり, 再採取は慎重になるべきであるという報 告 ${ }^{1011115)}$ も散見されることから我々は健側からの採取 または八ムストリングスを用いた方が安全であると考 

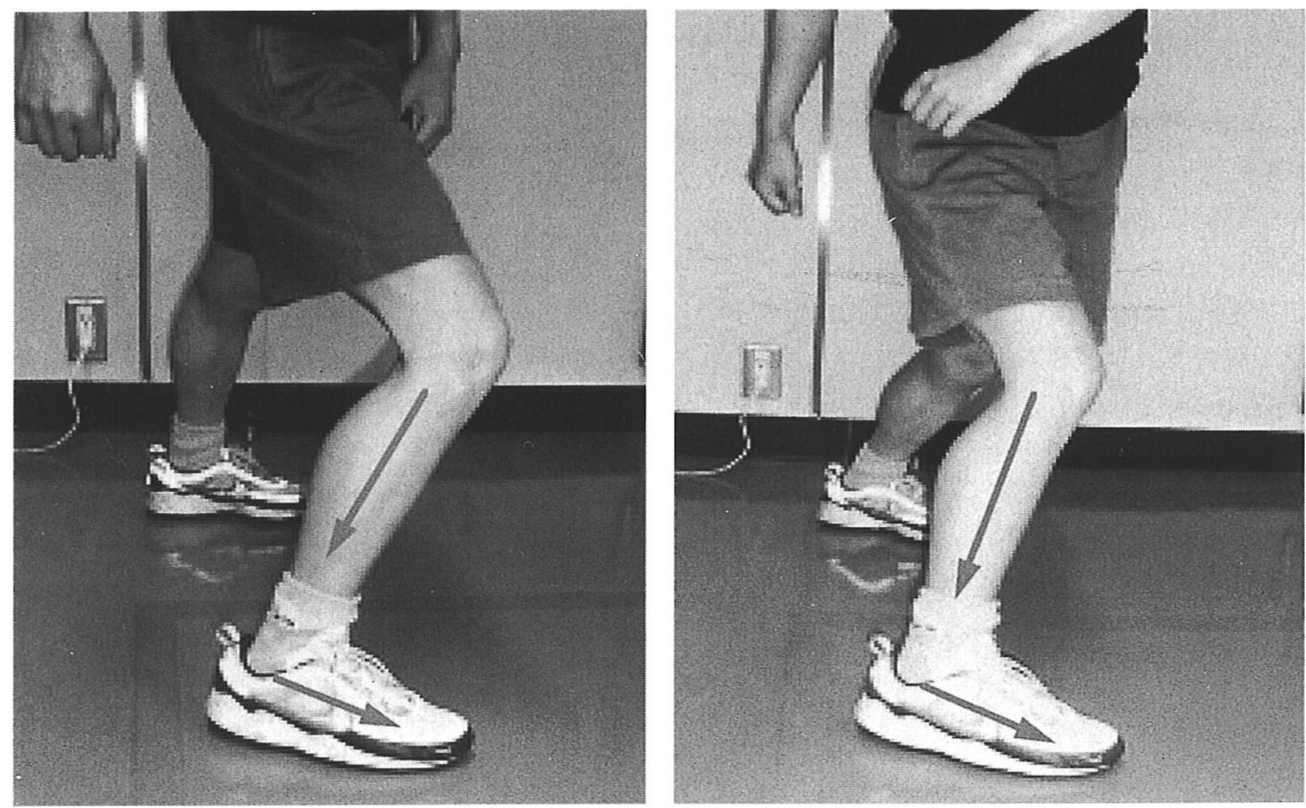

図 7 スポーツでのストップ, ターン時の滕外反, 下腿内旋の一定の受傷肢位の繰り返しによるものが多かった.
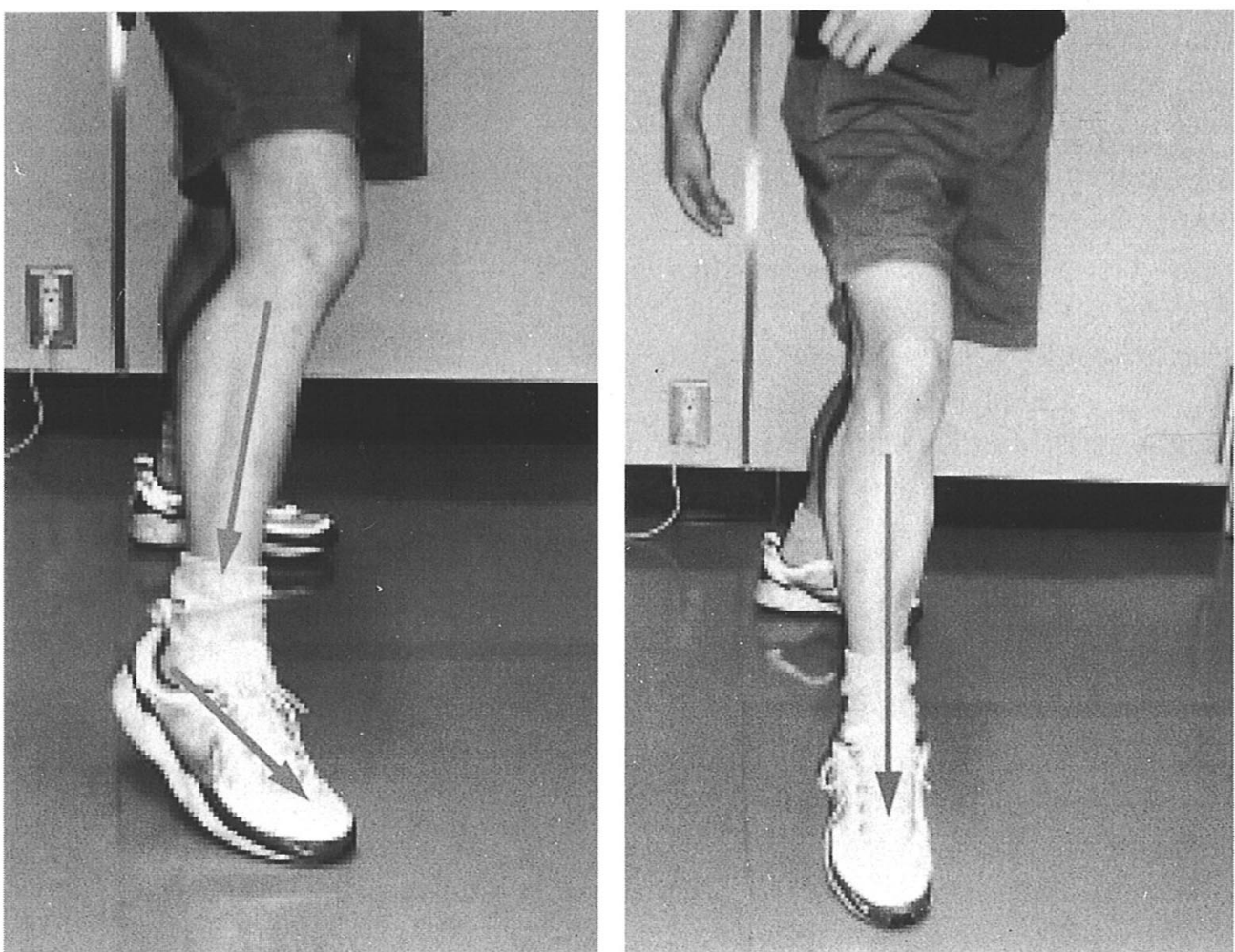

図 8 ツイスティング

下腿前傾させ膝関節屈曲位で踵部と足趾を浮かせて母趾球（第 1 趾 MTP 関節）を接地点（支点）として， 膝関節と足部の方向が一致するように下腿の回旋を繰り返す。 
えている．また史野 ${ }^{18)} ら は$ 新鮮凍結保存腱は自家組織 を犠牲にせずに，移植腱の長さと直径を自由に選択す ることが可能であり再々建術の移植材料としては理想 的であると述べているが, disease transmissionの 危険性なども報告されており 要すると思われる。 また人工勒带は, 術後早期からの リハビリテーションも可能でその成績は比較的良好で あるとの報告も散見される。しかし，人工勒帯の wear particleによる慢性滑膜炎, 関節水腫, 関節 軟骨変性などの問題も報告されている ${ }^{21)}$. 我々は過去 にDacron 人工勒帯を用いて再建を行った症例で良 好な成績が得られなかった20). それゆえに人工勒帯は 用いていない.

（3） ACL 再断裂の発生に対する予防法

初回再建時の手技として, 術中の正しい isometricity の獲得すなわち至適骨孔の作成 ${ }^{2)}$ を行 うことが重要ということはいうまでもない. また，再 建時および再鏡視での再建勒帯の impingementを 防止するために，顆間窩の狭小化を認める症例に対し ては notchplasty の追加を行うなどが考えられる. 反張膝のある症例に対しては再建 ACL の remodeling に必要な 6 ケ月間は支柱付き装具による伸展制限 を行う事も必要である. また, 術後十分な筋力が得ら れたうえでスポーツ復举を許可するべきと考えられる. 我々のプログラムは術後 6 ケ月で isokinetic machine の低角速度域として $60 \mathrm{deg} / \mathrm{sec}$, 高角速度域と

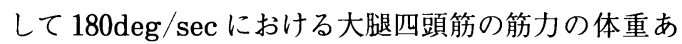
たりのピークトルク值（以下体重比）が $100 \%$ 以上, 体重比の患側と健側間の比（以下患健比）が $80 \%$ 以 上となった時点でスポーツ復帰を許可している ${ }^{1617)}$. 今回の再受傷パターンが全例スポーツでのストップ, ターン時の膝外反, 下腿内旋の繰り返しによることか ら再受傷防止のためにも，膝関節への回旋ストレスの 集中を回避する目的で, 下腿前傾させ膝関節屈曲位で 踵部と足趾を浮かせて母趾球（第 1 趾 MTP 関節）を 接地点（支点）として, 膝関節と足部の方向が一致す るように下腿の回旋を繰り返す（図 8）ツイスティン グの指導が有効であるとの報告もある ${ }^{3 / 9)}$. ツイスティ ング動作は滕関節にかかる内・外反力や内 ·外旋力の ストレスを減弱させるため安全で多くのスポーツ動作 で応用でき，またこの動作の習熟により ACL 再受傷 の予防に効果があると思われる. 今後は ACL 再建術
を施行されたスポーツ選手や指導者に対して, 正しい フットワークの指導を日常診療や現場で行っていく必 要性があると思われる。

\section{ま と め}

(1) ACLの再々建術を施行した 6 例の術後成績は初 回再建術よりやや劣る傾向にあった。

(2)再断裂の原因として一定の受傷肢位の繰り返しに よるものが考えられた。

(3)スポーツ外傷に伴う ACL 再断裂を予防するため には十分な術後療法の指導が必要と考えられた。

\section{参考文 献}

1) Buck, B. E. et al.: Bone transplantation and human immunodeficiency virus: an estimated risk of acquired immunodeficiency syndrome (AIDS). Clin Orthop, $240: 129-136,1989$.

2）藤原 明ほか：膝蓋腱を用いた前十字勒帯再建術にお ける骨孔作成の工夫一Rectangular bone tunnel の試 み一。整形外科と災害外科, $48: 324-328,1999$.

3）花田弘文ほか：バスケットボール選手の下肢スポーツ 外傷及び障害。整形外科と災害外科, 48(1)：165-168, 1998.

4) 原 道也ほか: 再建十字勒帯の MRI 所見と病理組織 像の比較. 日本整形外科学会雑誌, 71(8): 1599, 1997.

5) 原道也ほか: 膝前十字勒帯再建術後の膝蓋腱採取部 の経時的変化. 整形・災害外科, $41: 331-337,1998$.

6）井上雅裕, 史野根生：膝蓋腱を用いた前十字勒带再建 術における術後成績不良例の検討. 滕, $13: 91-93,1987$.

7) Johnson, D. L. et al.: Revision anterior cruciate ligament surgery; experience from Miami. Clin Orthop, $325:$ : 91-99, 1996.

8) Karns, D. J. et al.: Case report; revision anterior cruciate ligament reconstruction. Arthroscopy, 10 : 148-151, 1994.

9）小柳磨毅, 史野根生 : 膝 ACL 損傷に対するリハビリ テーション. 整形外科アスレチックリハビリテーション 実践マニュアル，97-107，1998.

10) LaPrade, R.F. et al.: The reharvest central third of the patellar tendon; a histologic and biomechanical analysis. Am. J. Sports Med, 25 : 779-785, 1997.

11) Liu, S. H. et al.: MRI and morphology of the insertion of the patellar tendon after graft harvesting. J. Bone Joint Surg, 78-B : 823-826, 1996.

12）三岡智規ほか: Revision ACL 再建術の問題点. 日本 整形外科スポーツ医学会雑誌, $15: 47-52,1995$.

13）緒方公介：膝十字勒帯再建における素材の選択一骨付 き膝蓋腱. 臨床整形外科, $27: 1249-1252,1992$.

14）緒方公介：骨付き膝蓋腱を使用した膝前十字勒帯再建 術. 日本整形外科学会雑誌, 66(3)：463-464, 1992. 
15) Proctor, C.S. et al.: Characterization of the repair tissue after removeal of the central one-third of the patellar ligament. J. Bone Joint Surg, 79-A : 9971006, 1997.

16）佐伯和彦ほか：前十字勒帯再建術後の筋力回復遅延例 に対する表面筋電図の有用性. 日本整形外科学会雑誌, $71(8): 1597,1997$.

17）佐伯和彦ほか：前十字勒帯再建術後の表面筋電図によ る術後療法の筋力および筋断面積回復への影響. 日本整 形外科学会雑誌, 72(8): 1273, 1998.

18) Shino, $K$. et al.: Reconstruction of the anterior cruciate ligament using allogenic tendon; long-term followup. Am J Sports Med, 17 : 595-600, 1990.

19) Uribe, J.W. et al.: Revision anterior cruciate ligment surgery; experience from Pittsburgh. Clin Orthop, $325:$ 100-109, 1996.

20）山田昌登嗣ほか：人工勒带を用いた ACL 再建例にお ける再断裂症例の検討. 整形外科と災害外科, 44(3): 956-958, 1995.

21）安田和則ほか：revision 前十字勒帯再建術式における 問題点とその解決法. 臨床整形外科, $29: 259-266,1994$. 